\title{
Impacts of big game on private land in south- western Montana: Landowner perceptions
}

\author{
JOHN R. LACEY, KEITH JAMTGAARD, LEX RIGGLE, AND TIFFANY HAYES
}

\begin{abstract}
Authors are extension range management specialist, Animal and Range Sciences Department; assistant professor, Sociology Department; range conservationist, Soil Conservation Service; and research assistant, Sociology Department. Riggle works out of the Sheridan Field Office at Sheridan. Mont., while the other authors work at Montana State University, Bozeman.
\end{abstract}

\begin{abstract}
Increasing populations of big game animals are a problem for private landowners in some parts of western North America. Influence of big game costs, hunting-related income, noneconomic benefits, size of private land holding, and proportion of total income from agriculture upon landowner management goals as well as perception of damage to forage resources were studied in 1989-1990 using a mail survey of 858 randomly selected southwestern Montana landowners. They reported that elk (Cervus canadensis) populations increased, did not change, or decreased on $71 \%, 25 \%$, or $4 \%$ of their private lands, respectively. Similar trends were reported for mule deer (Odocoileus hemionus), whitetail deer (Odocolleus virginia), and antelope (Antilocapra americana). More than $50 \%$ of the respondents thought that big game damaged forage and crop yields, while less than $2 \%$ of the respondents thought that big game was beneficial to forage and crop yields. Big game consumed mean of 511 AUMs per private landowner, which contributed to the mean big game cost of $\$ 6,353$ per landowner. Respondents desiring fewer elk, deer, and antelope outnumbered those desiring more by a 4-to-1 margin. As costs of big game increased and as dependency on agricultural income for livelihood increased, respondents desired fewer big game animals and perceived the impact of big game to be more harmful to forage and crop yields. Landowner attitudes toward blg game were not significantly affected by economic returns from big game. Although owners with larger land holdings were more likely to allow hunters access to hunt big game, owners of large- and of small-sized ranches generally regarded big game populations similarly. Results from this survey should be useful in forming natural resource policy.
\end{abstract}

Key Words: big game, landowner survey, private land, wildlife impact

Populations of many big game species are an interesting problem for many rural landowners in areas such as southwestern Montana. These animals are a public resource held for the public at large by individual states (Peek 1986). Yet some of the costs associated with the maintenance of these animals are borne by private landowners in the form of forage which would otherwise be consumed by privately held livestock, as well as damage to fences and other facilities.

Customary notions of rational action (Coleman 1990) hold that people, using the resources at their disposal, act in such a way as to

\footnotetext{
The survey was commissioned by the Big Game Committee of the Headwaters RC\&D, Inc., and was funded in part by Stockgrower and Grazing Associations in Southwest Montana, and H.B. 223 funds administered by the Department of Natural Resources and Conservation, Helena, Mont.

Manuscript accepted 4 Apr. 1992.
}

efficiently achieve their goals. This model can be applied to the case of big game and rural landowners. To the degree that big game interfere with management goals, some landowners are compensated by generating income from wildlife on private lands through both nonconsumptive use and hunting. However, game animals are under federal and state governmental regulation and control. There is no property right in wild animals until they are taken, confined, or domesticated in compliance with state and federal law (Kramer 1982). Although landowners do not own the game animals which inhabit their land, they do own the exclusive right to hunt them (subject to state laws) or to lease their property to another for similar purposes (Kramer 1982). The practice of charging access fees for hunting is more common in states that are predominately privately owned, rather than in states like Montana where federal land management agencies control much of the land (Thomas 1984).

Migratory patterns also limit the ability of landowners to respond to big game animals in a way which serves their interests. While these animals may spend considerable time on private land, and incur substantial costs while doing so, they often do so in seasons other than hunting season (Nielsen et al. 1986). In such cases, the production goals of landowners may be hindered by wildlife. From the perspective of the landowners, they bear some of the costs of producing these animals, but are unable to share in the benefits of their production (Krutilla 1967, Nielsen et al. 1986).

Landowners also consider noneconomic benefits of wildlife on their land (Applegate 1981). These include, but are not limited to, the enjoyment of observing big game animals and the satisfaction in knowing that they are there and using the habitat that was provided them.

In this paper, we examine the influence of big game costs, hunting related income, proportion of total income from agriculture, and noneconomic benefits upon landowner wildlife management goals as well as perception of damage to forage resources. Because costs and benefits associated with big game may be related to the size of land holding (Nielsen et al. 1986), size of operation is controlled in our analysis. Results are useful to: (1) improve communication and understanding between private landowners and sportsmen, (2) coordinate big game management on public and private land, and (3) provide data for natural resource policy makers.

\section{Methods}

The study area included 7 southwestern Montana counties, about 4.2 million ha (Fig. 1). Seventy-one percent of the land is range, pasture, or grazeable woodland (Headwaters RC\&D 1974). Five percent is used for crop production. Forty percent of the total area is privately owned, slightly more than half is administered by 


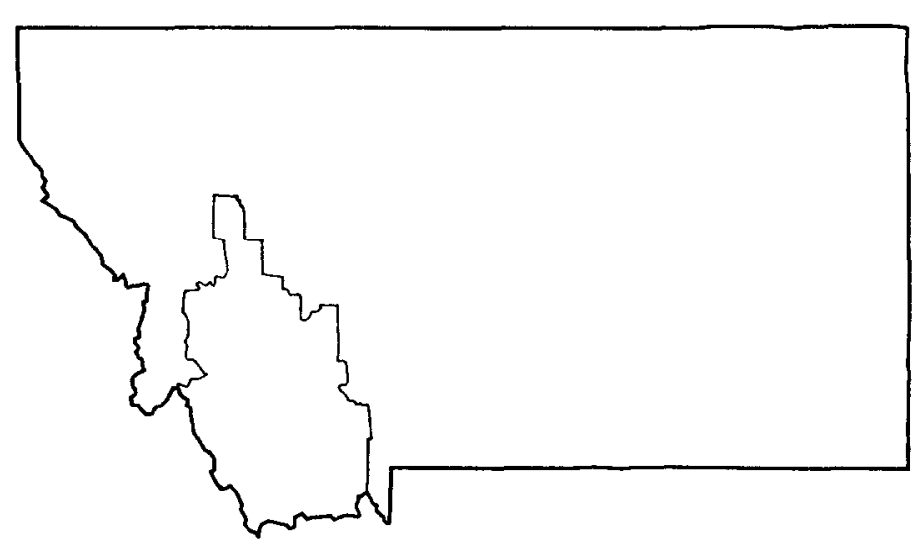

Fig. 1. The 7 counties in southwestern Montana included in the landownerbig game survey, 1989-1990.

the Forest Service (FS) and Bureau of Land Management (BLM), and the remainder is owned by the State of Montana. Livestock grazing on federal lands in the region is economically important (Lacey and Johnson 1990).

In December 1989, a self-administered, mail-back questionnaire (Dillman 1978) was mailed to 858 rural landowners. Individual landowners were randomly selected from an Agricultural Stabilization Conservation Service (ASCS) mailing list containing 1,959 names. The ASCS mailing list included all owners and operators of agricultural land, excluding subdivisions, in the study area. The percentage of landowners participating in the federal farm program is unknown. A second copy of the questionnaire was mailed in January, 1990, to landowners who failed to respond to the first mailing.

The questionnaire was designed to collect information from landowners on the impact of big game animals on their private land. Specific issues included the name of big game animals, benefits and costs associated with big game animals, and the compatibility of big game populations to private land management objectives. The possibility of landowners providing inflated estimates of big game numbers and of the length of time big game spent on private lands could not be evaluated. The analysis treated expense of repairing pasture fences damaged by big game, cost of labor and material (less the amount supplied by the State of Montana) to fence haystacks from big game, economic value of forage in haystacks that was consumed or ruined by big game, and value of private land forage consumed by big game as big game-related expenses incurred by landowners. It was assumed that forage consumed by big game could have been available for livestock. The probability of big game grazing reducing grain and hay yield and impairing long-term productivity of hay, range, and pasture lands were not included in the analysis. Likewise, forage consumed by big game was dependent on number of days that a specific type of land was used. No distinction was made between the value of forage harvested on different kinds of land.

Fees charged for grazing on federal lands are controversial. Price paid for forage to graze a mature cow of approximately 455 $\mathrm{kg}$ for 1 month on private land in Montana averaged \$1 1.00, \$0.35 less than the average price paid to graze a cow-calf pair for a month of grazing on private land (USDA 1990). To place a monetary value on forage harvested by big game from private land, the Montana rate was used. Ranchers paid $\$ 1.86$ to graze a mature cow weighing approximately $445 \mathrm{~kg}$, either dry or with calf up to 6 months of age, on public land for 1 month. The traditional logic given for the lower fee on public land is the need to encourage good stewardship and private investment on public lands, higher nonfee costs of grazing on public lands, and the out-of-pocket expense incurred when current leaseholders bought the grazing permit from original leaseholders (Torell and Doll 1991). Although the latter value (cost) has never been recognized by public land agencies, the Internal Revenue Service taxes the value of the estate when leases transfer. Regardless, many nonranchers and some ranchers who do not have a federal land grazing permit believe that the grazing fee is a subsidy and advocate reductions in federal land grazing (Hadley and Carrol 1986, National Wildlife Federation 1990, Gillis 1991).

An index of intangible benefits from big game was derived by summing the respondents' responses to the receipt of nonmonetary benefits (enjoy having them, hunting by family, hunting by friends, and other). The index ranged from 0 to 4 for respondents receiving either none, or recognizing benefits in all 4 categories. The mean, median, and standard deviation of the index were $1.4,1.0$, and 1.2 , respectively.

Frequency and bivariate analyses were used to summarize response to each question. Chi square analyses were used to compare the impact of big game damage among 6 types of land. Logistic and ordinary least squares regressions were used to examine influence of agricultural income, amount of land in private ownership, and big game populations on landowner satisfaction. Evidence of multicollinearity for logistic regression was evaluated by reviewing standard errors (Hosmer and Lemeshow 1989). No evidence of collinearity, as a result of a relationship between size of operation, proportion of income from agriculture, economic cost of big game, economic income from big game, or the index of intangible value of big game was found. Collinearity in the ordinary least squares regressions was checked by calculating and examining condition numbers (Kmenta 1986). A probability level of $5 \%(0.05)$ was used in all regression analyses. A study of nonrespondents was not conducted, nor was nonresponse bias evaluated.

\section{Results and Discussion}

\section{Characterization of Respondents}

A total of 456 questionnaires containing useful information was returned (53\% response rate). Respondents were fairly welldistributed among 7 size classes (Fig. 2). However, the U.S. Census

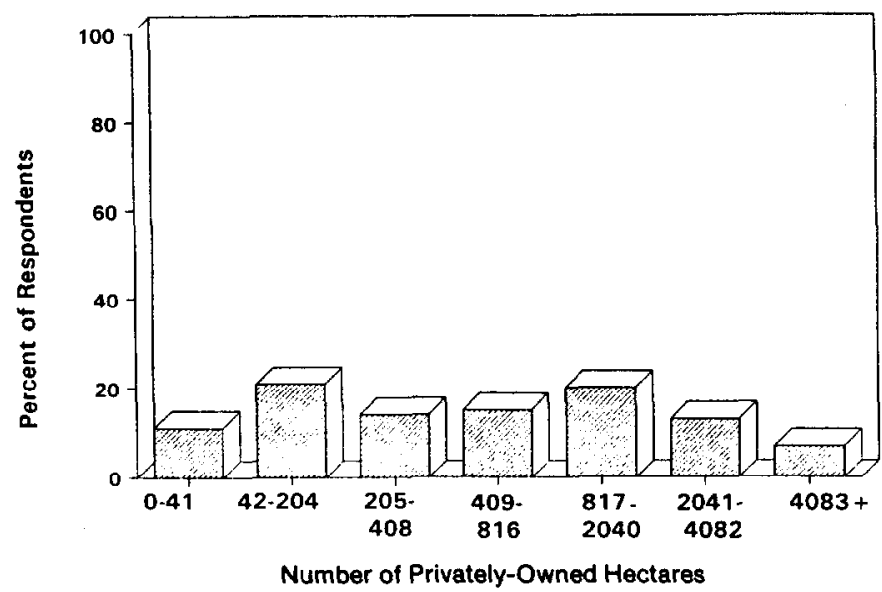

Fig. 2. Percent of respondents by land ownership patterns, landowner-big game survey, 1989-90.

of Agriculture (1987) reported a total of 1,657 ranches and farms in the study area, of which $46 \%$ and $40 \%$ are less than 202 ha and more than $\mathbf{4 0 9}$ ha, respectively. Therefore, in comparison to the Census, respondents to our survey represented a higher percentage of large landowners. In order to understand the consequences of this, size of operation was treated as a control variable in our analyses. Data 
indicate size to be relatively unimportant.

Thirty-seven percent of the respondents had a BLM grazing lease, averaging 437 animal unit months (AUMs). Thirty-two percent of the respondents had FS grazing leases, averaging 1,082 AUMs. Thirty-three percent of the respondents controlled stategrazing leases, which averaged $687 \mathrm{ha}$ in size.

Agricultural income represented a major part of the total income of most respondents (Fig. 3). Overall, the percent of total income from the farm/ ranch enterprise averaged $75 \%$.

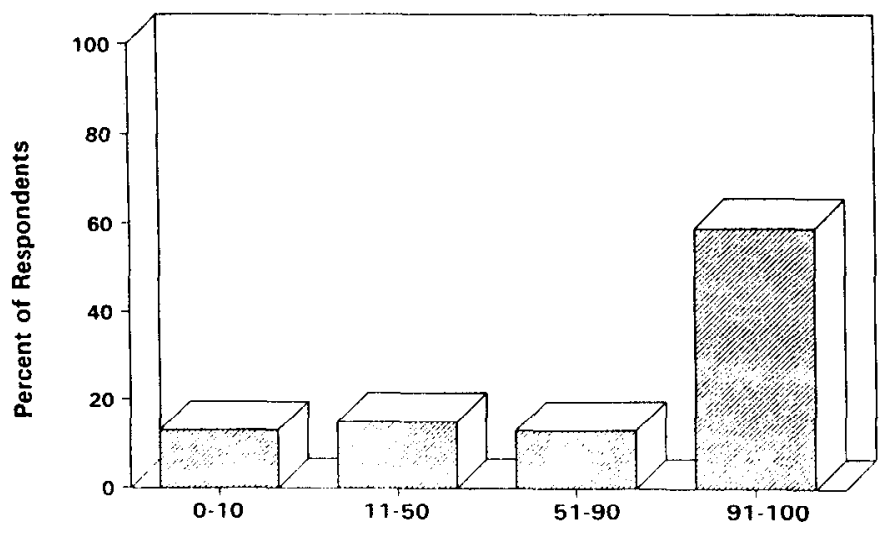

Agricultural Proportion of Total income (Percent)

Fig. 3. Proportion of total income earned from agricultural production, as reported by respondents in landowner-hig game survey, 1989-90.

Eight percent of the landowners had land enrolled in the Conservation Reserve Program (CRP). Although 70\% of the CRP participants had fewer than 204 ha in the program, $80 \%$ of the CRP seedings were used by mule deer (Odocoileus hemionus), whitetail deer (Odocoileus virginia), and antelope (Antilocapra americana).

\section{Estimated Economic Impact of Big Game Populations}

Costs attributed to big game averaged $\$ 6,467$ per landowner (Table 1). The average cost attributed to forage consumption, hay stack damage, fencing haystacks, and repairing pasture fences damaged by big game are explained below. Landowner costs of providing information, assisting hunters, patrolling, repairing roads, and general nuisance are not included. The estimate also does not consider long-term resource damage resulting from the inability to control the time and degree of grazing by big game. These data support the contention that the interaction between livestock production and big game is often competitive (Smith 1961, Stoddard et al. 1975, Austin and Urness 1987, Nielsen and McBride 1989, Edge and Marcum 1990, Jackson 1991, Adkins 1991) and that big game management is an important economic
Table 1. Comparison of mean economic costs and returns from big game animals on private land in southwestern Montana, as derived from landowner-big game survey, 1989-1990.

\begin{tabular}{llc}
\hline \hline $\begin{array}{l}\text { Mean estimated } \\
\text { impact } / \text { landowner }\end{array}$ & $\begin{array}{l}\text { Quantity and } \\
\text { Value }\end{array}$ & Dollars \\
\hline $\begin{array}{l}\text { Cost } \\
\text { Forage consumption }\end{array}$ & 511 AUMs @ \$11 & $\begin{array}{c}5,6161 \\
(10561)^{2} \\
450 \\
(1040)\end{array}$ \\
Damage to hay stack & 7.5 tons @ \$60 & 119 \\
Fencing & & $(451)$ \\
Haystack & Labor \& Material & 169 \\
Pasture & & $(258)$ \\
Labor & 5.3 days @ \$32/day & 113 \\
Material & Posts and wire & $(146)$ \\
Total Cost & (unspecified) & 6,467 \\
Economic Return & & $(11227)$ \\
Hunting Access Fees & & 114 \\
$\quad$ Total Return & & $(1025)$ \\
Net Estimated Cost & & $(114$ \\
\hline
\end{tabular}

Actual dollar value does not correspond to product of quantity and value due to rounding of AUMs to nearest integer.

2Standard deviation.

consideration on private land where big game animals compete with livestock for forage, trample forage and wet soils, and damage crops and fences (Pineo 1985, Gasson 1985, Nielsen et al. 1986, Lacey et al. 1988).

Big game were not uniformly distributed throughout the study area. Slightly over three-quarters of the respondents reported mule deer and whitetail deer use on private land (Table 2). Over half of the respondents reported elk (Cervus canadensis) use. Antelope, moose (Alces alces), and big horn sheep (Ovis canadensis) were reported on a smaller percentage of ranches. By evaluating numbers, animal size, and length of time spent on private lands, it was estimated that big game consumed 511 AUMs per landowner (Table 2). However, the median was 169 , indicating that half of the respondents reported less than 169 AUMs of big game use. Elk and mule deer accounted for about $40 \%$ and $30 \%$ of the total AUMs used, respectively. Because of lower populations and less time spent on private land, consumption by antelope, bighorn sheep, and moose accounted for $13 \%$ of the total forage consumed by big game. The cost of forage consumption by big game averaged $\$ 5,616$ per landowner (Table 1).

Table 2. Occurrence of big game, big game uses and estimated forage consumption on privately owned acreage in southwestern Montana, as reported by landowners in 1989-1990 survey.

\begin{tabular}{|c|c|c|c|c|c|}
\hline $\begin{array}{l}\text { Kind of } \\
\text { big game }\end{array}$ & $\begin{array}{l}\text { Occurrence of big } \\
\text { game on ranches } \\
\text { (\% of total) }\end{array}$ & $\begin{array}{c}\text { Total big game } \\
\text { use }^{1}\end{array}$ & $\begin{array}{c}\text { Mean big game } \\
\text { use }^{2}\end{array}$ & $\begin{array}{l}\text { Forage consumption } \\
\text { equivalent }{ }^{3}\end{array}$ & $\begin{array}{c}\text { Mean animal unit } \\
\text { months }\end{array}$ \\
\hline Mule deer & 78 & 395,568 & 869 & .17 & 147 \\
\hline Elk & 56 & 183,600 & 404 & 0.53 & 214 \\
\hline Antelope & 46 & 221,360 & 487 & 0.10 & 49 \\
\hline Moose & 30 & 7,911 & 17 & 0.87 & 15 \\
\hline
\end{tabular}

$1 \sum_{i=1}^{456}\left(\sum_{=1}^{6} a_{j k} X_{j k}\right) ;$ where $\mathrm{j}=$ respondents, $k=$ big game species, $a=$ number of big game and $\mathrm{x}=$ number of months on private land.

${ }^{2}$ Calculated by dividing total big game use by number of respondents.

${ }^{3}$ Forage demand of big game animals calculated on basis of body weight and expressed in relation to a cow, or 1 animal unit (Stoddard and Smith 1955, p. 192). 
Forty-nine percent of the respondents reported big game damage to hay stacks. Of these, $65 \%$ experienced a loss between 1 and 10 tons. Since $7 \%$ reported damage on more than 51 tons, the loss per respondent averaged 7.5 tons (Table 1). Damage to haystacks was higher in areas with higher big game populations.

Thirty-six percent of respondents fenced their stackyards to reduce big game damage. Cost of labor and material averaged \$1 19 per respondent (Table 1). Forty-five percent of respondents reporting damage requested, and nearly all of these received, assistance (usually fencing materials) from Montana's Department of Fish, Wildlife, and Parks.

Sixty-four percent of respondents reported that big game damage to pasture fences resulted in additional management cost. Value of labor and materials to repair the fences averaged $\$ 169$ and $\$ 113$ per landowner, respectively (Table 1 ).

More than half $(54 \%)$ of the respondents reported that big game impact other aspects of the ranching operation beyond damage to fences and haystacks. Hay and grain harvest schedules were altered on $35 \%$ and $24 \%$, respectively, of the operations. Eighty-seven percent of the landowners reported their income was adversely affected by the "general inconvenience" of big game. Much of the latter costs were associated with providing assistance to hunters. These costs were not quantified in the present study.

Four percent of the respondents earned income from the big game on their private lands. Hunting rights were either leased to outfitters, or hunters were charged an access fee. Most of these landowners earned between $\$ 1,000$ and $\$ 5,000$ from their hunting enterprises, thus approaching the mean annual cost attributed to big game. A mean income of $\$ 114$ per landowner was calculated by dividing the total big game-generated income by 456 landowners. The net economic cost of big game per respondent was $\$ 6,353$ (estimated cost of $\$ 6,467$ less the $\$ 114$ income from marketing hunting opportunities) (Table 1).

The annual cost $(\$ 6,353)$ of supporting big game on private land is not directly associated with the value of private land for big game hunting. Most of the respondents (77\%) allowed big game hunters access to their privately owned lands. They reported a mean of 227 days of big game hunting on their private lands. Nineteen percent of the activity was described as trespass. By dividing \$6,353 (the cost of big game) by the mean number of hunting days (227), the estimated value for each day of big game hunting is $\$ 28$. However, the value of big game hunting is frequently reported to be much higher (Duffield 1988, Loomis and Cooper 1988, Brooks 1988). Landowners bear a cost while supporting an activity which provides benefits to the hunting public and community. This economic disparity may explain why many landowners feel that their contributions to big game hunting opportunities are seldom recognized and usually unrewarded (Nielsen et al. 1986, Lacey et al. 1988, Jordan and Workman 1989, McKetta and Bolan 1990, Rimbey et al. 1991). Some landowners deny hunter access to private lands because they perceive the potential for intentional and unintentional vandalism (to roads, fences, and other facilities), spread of noxious weeds, and fear their susceptibility to liability claims. Some landowners desire compensation for providing wildlife habitat and recreational opportunities (Lacey et al. 1988, McKetta and Bolon 1990). The compensation issue is controversial because sportsmen recognize big game as a public resource (Hadley and Carroll 1986, Headwaters RC\&D 1990).

Table 3. Regression of wildlife populations on importance of agricultural income and hectares of privately-owned land, as reported by respondents in landowner-big game survey, 1989-1990.

\begin{tabular}{|c|c|c|c|c|}
\hline \multirow{2}{*}{$\begin{array}{l}\text { Big game } \\
\text { animal }\end{array}$} & \multirow{2}{*}{$\begin{array}{l}\text { Number of } \\
\text { respondents }\end{array}$} & \multicolumn{3}{|c|}{ Parameters ${ }^{1}$} \\
\hline & & Intercept & Income & Hectares \\
\hline Mule deer & 387 & $\begin{array}{c}1.6 \\
(31.1)^{2}\end{array}$ & $\begin{array}{l}+0.16 \\
(0.42)\end{array}$ & $\begin{array}{l}+0.05^{* * * *} \\
(0.01)\end{array}$ \\
\hline Whitetail deer & 387 & $\begin{array}{r}2.45 \\
(20.1)\end{array}$ & $\begin{array}{l}+0.49 \\
(0.27)\end{array}$ & $\begin{array}{l}+0.01^{* * *} \\
(0.00)\end{array}$ \\
\hline Elk & 387 & $\begin{array}{c}23.6 \\
(50.9)\end{array}$ & $\begin{array}{l}-0.26 \\
(0.68)\end{array}$ & $\begin{array}{l}+0.08^{* * *} \\
(0.01)\end{array}$ \\
\hline Antelope & 387 & $\begin{array}{c}-3.3 \\
(16.9)\end{array}$ & $\begin{array}{l}-0.07 \\
(0.23)\end{array}$ & $\begin{array}{l}+0.02^{* * *} \\
(0.00)\end{array}$ \\
\hline Moose & 387 & $\begin{array}{c}1.32 \\
(6.43)\end{array}$ & $\begin{array}{c}+0.04 \\
(0.09)\end{array}$ & $\begin{array}{l}+0.004^{* * *} \\
(0.00)\end{array}$ \\
\hline Bighorn sheep ${ }^{3}$ & & & & \\
\hline
\end{tabular}

$1 *, * * * * *$ Significant at the $0.05,0.01$, and 0.001 levels, respectively.

2Staridard error

${ }^{3}$ Regression analyses inappropriate due to low number of respondents with big horn sheep.

\section{Intangible Value of Big Game on Private Lands}

Half of the respondents indicated that they "enjoyed having big game on their private lands." About three-fifths of the respondents reported hunting by family members, neighbors, and friends as benefits. Nearly one-third of the respondents reported that the big game animals on their private land did not provide them with any intangible (nonmonetary) benefits.

About $75 \%$ of the landowners either thought that the presence of big game did not influence or did not know if resale value of private land was influenced by big game. The likelihood of big game increasing or decreasing resale value was reported by $21 \%$ and $2 \%$ of respondents, respectively.

\section{Factors Influencing Landowner Attitudes Toward Big Game}

Respondents who had operated their ranch for more than 10 years were asked about trend of big game populations on their private lands. Over $70 \%$ of the respondents indicated that the numbers of whitetail deer and elk had increased on their land during this period (Fig. 4). Data from the Montana Department of

Table 4. Logistic regression of big game impact to haystacks (yes/no), fencing costs (yes/no), and hunting access on percent of income from agriculture, hectares of privately-owned land, and big game populations.'

\begin{tabular}{|c|c|c|c|c|c|}
\hline \multirow[b]{2}{*}{ Item } & \multirow{2}{*}{$\begin{array}{c}\text { Number of } \\
\text { observations }\end{array}$} & \multicolumn{4}{|c|}{ Parameters $^{2}$} \\
\hline & & Intercept & Income & Hectare & Big game \\
\hline Damaged haystack & 366 & $\begin{array}{l}1.73^{* * *} \\
(0.309)^{3}\end{array}$ & $\begin{array}{l}0.021^{* * *} \\
(0.0039)\end{array}$ & $\begin{array}{c}0.00008 \\
(0.00005)\end{array}$ & $\begin{array}{l}-0.0009 * * * \\
(0.0002)\end{array}$ \\
\hline Fence hay & 353 & $\begin{array}{r}0.73^{* *} \\
(0.273)\end{array}$ & $\begin{array}{l}-0.0018 \\
(0.0035)\end{array}$ & $\begin{array}{c}0.00004 \\
(0.00005)\end{array}$ & $\begin{array}{l}-0.0003^{*} \\
(0.0001)\end{array}$ \\
\hline Hunting access & 369 & $\begin{array}{l}0.47 \\
(0.25)\end{array}$ & $\begin{array}{l}0.025^{* * *} \\
(0.004)\end{array}$ & $\begin{array}{l}-0.00005 \\
(0.00008)\end{array}$ & $\begin{array}{l}-0.0002 \\
(0.0003)\end{array}$ \\
\hline
\end{tabular}

Coefficients normalized with respect to "no". For example, the 0.021 income estimate for damaged haystacks indicates that as the percent income coming from agriculture increases, the probability of respondents indicating "yes" to the item increased relative to those reporting "no". $2 *, * *, * * *$ Significant at $0.05,0.01$, and 0.001 levels, respectively.

3Standard error. 
Fish, Wildlife, and Parks (1986-1987a, 1986-1987b) also indicate that elk have increased 4- to 5-fold in many parts of southwestern Montana. Over half of the respondents also reported increases in mule deer and antelope (Fig. 4). From 3-10\% of the respondents reported these big game populations declining. In contrast, big horn sheep and moose populations were thought to be fairly stable over the past 10 years (Fig. 4).
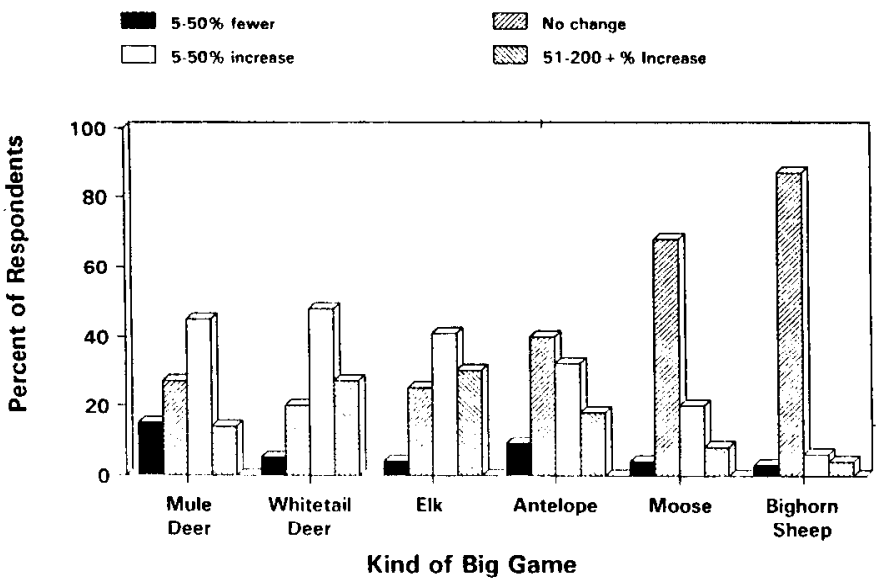

Fig. 4. Change in big game populations on private land in southwestern Montanta, as reported by respondents in landowner-big game survey, 1989-90.

Big game populations reported by respondents were correlated with the size of private land holdings. More big game animals were reported by large, rather than by small landowners (Table 3). It is not known whether animal populations were influenced by habitat quality or simply reflect more animals on a larger land base. However, source of income was not significantly correlated with reports of game populations.

Labor required to repair fence was not related to size of operation or source of income. Additional labor was required on ranches with higher big game populations (Table 4). As relative importance of agricultural income and big game population increased, respondents were more likely to report higher fencing costs (Table 4). Size of operation was not useful for explaining hay damage.

Percentage of landowners fencing hay stacks did not vary among land sizes nor with relative importance of agricultural incomes (Table 4). However, landowners reporting higher big game populations were more likely to fence hay stacks.

Respondents assessed the effect of big game on ranch management goals. About half of the respondents were satisfied with current populations (Fig. 5). However, from $32 \%$ to $44 \%$ of

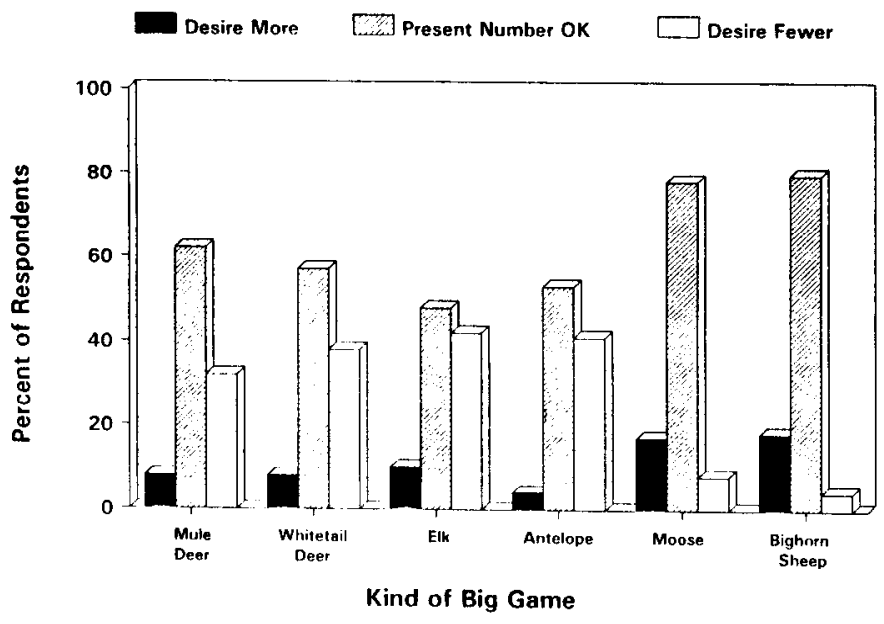

Fig. 5. Landowner satisfaction with big game populations on private land in southwestern Montana, as reported by respondents in landowner-big game survey, 1989-90.

respondents desired fewer elk, antelope, whitetail deer, and mule deer (Fig. 5). For all species except bighorn sheep and moose, the number of respondents desiring fewer big game animals on their land outnumbered those desiring more, by a 4-to 1-margin. In the case of bighorn sheep and moose, there were more respondents desiring population increases than decreases.

As dependency on agricultural income increased, landowners desired fewer mule deer, whitetail deer, and elk (Table 5). As the economic cost of big game increased, the probability also increased

Table 5. Logistic regression of big game satisfaction [(present number $\mathrm{OK}$ or desire more)/(desire fewer)] on percent of income from agriculture, bectares of privately owned land, estimated economic cost of big game, reported economic income from big game, and an index of intangible value of big game as reported by respondents in landowner-big game survey, 1989-19901.

\begin{tabular}{|c|c|c|c|c|c|c|c|}
\hline \multirow{2}{*}{$\begin{array}{l}\text { Big game } \\
\text { animal }\end{array}$} & \multirow{2}{*}{$\begin{array}{l}\text { Number of } \\
\text { respondents }\end{array}$} & \multicolumn{6}{|c|}{ Parameter $^{2}$} \\
\hline & & Intercept & Income & Hectare & BG Cost & BG Income & BG Intangible \\
\hline Mule deer & 308 & $\begin{array}{c}1.8^{* * *} \\
(0.45)^{3}\end{array}$ & $\begin{array}{l}-0.018^{* * * *} \\
(0.005)\end{array}$ & $\begin{array}{l}0.0001 \\
(0.00006)\end{array}$ & $\begin{array}{l}-0.00005^{* * * *} \\
(0.00002)\end{array}$ & $\begin{array}{l}-0.0001 \\
(0.0001)\end{array}$ & $\begin{array}{l}0.33^{* *} \\
(0.12)\end{array}$ \\
\hline Whitetail deer & 326 & $\begin{array}{l}1.6^{* * *} \\
(0.42)\end{array}$ & $\begin{array}{l}-0.02 * * * \\
(0.005)\end{array}$ & $\begin{array}{c}0.00008 \\
(0.00006)\end{array}$ & $\begin{array}{l}-0.00005^{* *} \\
(0.00002)\end{array}$ & $\begin{array}{c}0.00009 \\
(0.0001)\end{array}$ & $\begin{array}{l}0.49^{* * *} \\
(0.11)\end{array}$ \\
\hline Elk & 236 & $\begin{array}{l}2.1^{* * *} \\
(0.52)\end{array}$ & $\begin{array}{l}-0.022^{* * * *} \\
(0.006)\end{array}$ & $\begin{array}{l}-0.00001 \\
(0.00006)\end{array}$ & $\begin{array}{l}-0.00004^{*} \\
(0.00002)\end{array}$ & $\begin{array}{l}0.0000006 \\
(0.0001)\end{array}$ & $\begin{array}{c}0.21 \\
(0.12)\end{array}$ \\
\hline Antelope & 203 & $\begin{array}{l}1.4^{* *} \\
(0.50)\end{array}$ & $\begin{array}{l}-0.008 \\
(0.006)\end{array}$ & $\begin{array}{l}-0.00008 \\
(0.00006)\end{array}$ & $\begin{array}{l}-0.00006^{* *} \\
(0.00002)\end{array}$ & $\begin{array}{l}0.00009 \\
(0.0001)\end{array}$ & $\begin{array}{l}0.17 \\
(0.13)\end{array}$ \\
\hline Moose & 149 & $\begin{array}{l}14.1 \\
(12.3)\end{array}$ & $\begin{array}{l}-0.131 \\
(0.12)\end{array}$ & $\begin{array}{l}-0.0002 \\
(0.0001)\end{array}$ & $\begin{array}{l}0.00005 \\
(0.00004)\end{array}$ & $\begin{array}{c}0.0007 \\
(0.0014)\end{array}$ & $\begin{array}{c}0.50 \\
(0.28)\end{array}$ \\
\hline
\end{tabular}

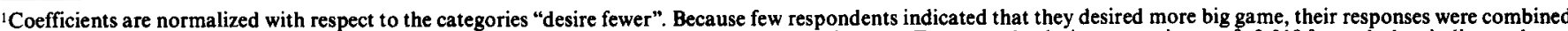

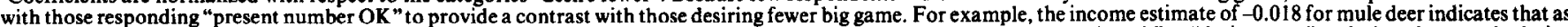

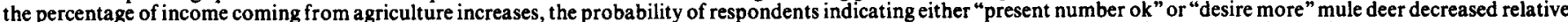

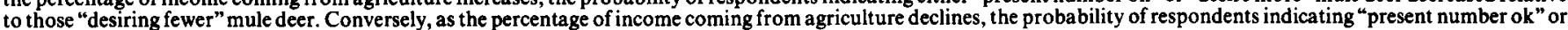
"desire more" mule deer increased relative to those "desiring fewer" mule deer.

$2 *, * *, * * *$ significant at the $0.05,0.01$, and 0.001 levels, respectively.

3 Standard error.

${ }^{4}$ Regression analyses inappropriate due to low number of respondents "desiring fewer" big horn sheep.
} 
that respondents would indicate that they desired fewer animals. After controlling for source of income and presence of big game, size of operation and income from big game did not influence the degree of satisfaction with any big game species (Table 5). For mule and whitetail deer, respondents were more likely to say they wanted more as the index of intangible benefits increased. The relationship was not significant for antelope, elk, or moose.

Most respondents indicated that big game either has no impact, or a negative impact on forage and crop yields from private land (Table 6). Reported damage was concentrated in alfalfa and grain fields, and was less in woodland. For each land type, as the landowner's dependence on agricultural income increased, landowners

Table 6. Impact of big game on forage and/or crop yield from private land, as described by respondents in landowner-big game survey, 1989-1990.

\begin{tabular}{lcccc}
\hline \hline \multirow{2}{*}{$\begin{array}{l}\text { Kind of land } \\
\text { or crop }\end{array}$} & \multirow{2}{*}{$\begin{array}{c}\text { Number of } \\
\text { respondents }\end{array}$} & \multicolumn{3}{c}{ Kind of Impact } \\
\cline { 3 - 5 } & & Beneficial & None & Harmful \\
\hline Alfalfa & 292 & $2^{\mathrm{a}}$ & $30^{\mathrm{a}}$ & $68^{\mathrm{a}}$ \\
Grain & 220 & $1^{\mathrm{a}}$ & $36^{\mathrm{a}}$ & $63^{\mathrm{a}}$ \\
Pasture & 341 & $2^{\mathrm{a}}$ & $44^{\mathrm{b}}$ & $54^{\mathrm{b}}$ \\
Grass hay & 296 & $1^{\mathrm{a}}$ & $45^{\mathrm{b}}$ & $53^{\mathrm{b}}$ \\
Range & 299 & $1^{\mathrm{a}}$ & $49^{\mathrm{b}}$ & $50^{\mathrm{b}}$ \\
Woodland & 202 & $5^{\mathrm{b}}$ & $78^{\mathrm{c}}$ & $17^{\mathrm{c}}$ \\
\hline
\end{tabular}

Means within a column followed by the same letter are not significantly different at the 0.05 probability level, as determined using Chi square analyses. were more likely to respond that big game had a harmful impact on forage and crop yields (Table 7). Landowners who were less dependent on agricultural income were more likely to report no impact or beneficial impact from big game (Table 7). As reported economic cost of big game increased, so did the likelihood that respondents would indicate that the big game was having a "harmful" effect on yields. Size of landholding and income from big game were not useful explanatory variables. As the index to intangible value of big game increased, respondents were more likely to indicate no impact or beneficial impact on pasture and grass hay (Table 7).

Probability of landowners allowing hunters access to private lands increased with the relative importance of agriculture in total income (Table 4). Access to private land was not influenced by size of land nor reported big game numbers.

Number of hunter days was positively associated with ranch size and with big game populations. Number of hunter days was not influenced by relative importance of agricultural income (Table 8).

In summary, big game adversely impact landowner income in Southwestern Montana. Number of respondents desiring fewer big game animals on their private land exceeded the number desiring more animals. Landowners exposed to high big game populations were less tolerant than those exposed to low big game numbers. Landowner attitudes toward big game were influenced by dependency on agricultural income and cost of big game: Income from big game and noneconomic values were less important as explanatory variables. Data indicate that landowners in areas such as

Table 7. Logistic regression of impact of big game on yield of private land [(no effect or beneficial effect on yield)/(harmful effect on yield)] on percent income from agriculture, hectares of privately-owned land, estimated economic cost of big game, reported economic income from big game, and an index of the intangible value of big game.

\begin{tabular}{|c|c|c|c|c|c|c|c|}
\hline \multirow[b]{2}{*}{ Kind of land } & \multirow{2}{*}{$\begin{array}{l}\text { Number of } \\
\text { respondents }\end{array}$} & \multicolumn{6}{|c|}{ Parameter $^{2}$} \\
\hline & & Intercept & Income & Hectare & BG Cost & BG Income & BG Intangible \\
\hline Range & 257 & $\begin{array}{l}1.98^{* * * *} \\
(0.49)^{3}\end{array}$ & $\begin{array}{l}-0.022^{* * * *} \\
(0.005)\end{array}$ & $\begin{array}{c}0.00003 \\
(0.00006)\end{array}$ & $\begin{array}{l}-0.0001^{* * *} \\
(0.00003)\end{array}$ & $\begin{array}{c}-0.0016 \\
(0.0002)\end{array}$ & $\begin{array}{c}0.288 \\
(0.132)\end{array}$ \\
\hline Pasture & 292 & $\begin{array}{l}1.45^{* * *} \\
(0.39)\end{array}$ & $\begin{array}{l}0.018^{* * *} \\
(0.005)\end{array}$ & $\begin{array}{c}-0.00002 \\
(0.00006)\end{array}$ & $\begin{array}{c}-0.0002^{* * *} \\
(0.00003)\end{array}$ & $\begin{array}{c}0.0002 \\
(0.0002)\end{array}$ & $\begin{array}{c}0.38 * * \\
(0.13)\end{array}$ \\
\hline Grass hay & 263 & $\begin{array}{l}1.33^{* * * *} \\
(0.44)\end{array}$ & $\begin{array}{l}-0.018^{* * * *} \\
(0.005)\end{array}$ & $\begin{array}{c}0.000004 \\
(0.00006)\end{array}$ & $\begin{array}{c}-0.00009 * * * \\
(0.00003)\end{array}$ & $\begin{array}{c}0.0002 \\
(0.0001)\end{array}$ & $\begin{array}{l}0.31 * * \\
(0.12)\end{array}$ \\
\hline Alfalfa & 256 & $\begin{array}{l}1.10^{* *} \\
(0.40)\end{array}$ & $\begin{array}{l}-0.018^{* * * *} \\
(0.005)\end{array}$ & $\begin{array}{c}0.00002 \\
(0.00007)\end{array}$ & $\begin{array}{l}-0.00009^{* *} \\
(0.00003)\end{array}$ & $\begin{array}{c}0.0002 \\
(0.0001)\end{array}$ & $\begin{array}{l}-0.070 \\
(0.13)\end{array}$ \\
\hline Grain & 189 & $\begin{array}{l}1.9^{* * * *} \\
(0.55)\end{array}$ & $\begin{array}{l}-0.03^{* * *} \\
(0.006)\end{array}$ & $\begin{array}{c}0.00006 \\
(0.00007)\end{array}$ & $\begin{array}{c}-0.00006^{*} \\
(0.00003)\end{array}$ & $\begin{array}{c}-0.00007 \\
(0.0003)\end{array}$ & $\begin{array}{c}-0.08 \\
(0.14)\end{array}$ \\
\hline Woodland & 179 & $\begin{array}{l}3.15^{* * *} \\
(0.78)\end{array}$ & $\begin{array}{c}-0.019^{*} \\
(0.008)\end{array}$ & $\begin{array}{c}0.00006 \\
(0.0008)\end{array}$ & $\begin{array}{c}-0.00002 \\
(0.00002)\end{array}$ & $\begin{array}{c}0.0003 \\
(0.0006)\end{array}$ & $\begin{array}{c}-0.072 \\
(0.178)\end{array}$ \\
\hline
\end{tabular}

'Coefficients normalized with respect to the category "effect on yield is harmful". For example, the -0.022 income estimate for range indicates that as the percentage of income coming from agriculture increases, the probability of respondences indicating "no effect" or "beneficial" effect on yield decreased relative to those reporting "effect on yield is harmful". Because few respondents indicated effect on yield is "beneficial", these responses were combined with those responding "no effect" on yield to provide a contrast with those reporting harmful effects on yield.

$2 *, * *, * * *$ Significant at the $0.05,0.01$, and 0.001 levels, respectively.

3Standard error.

Table 8. Regression of number of hunter days, increased labor, and fencing materials cost on percent of income from agriculture, hectares of privately owned land, and big game populations.

\begin{tabular}{lccccc}
\hline \hline & \multirow{2}{*}{$\begin{array}{c}\text { Number of } \\
\text { respondents }\end{array}$} & Intercept & Income & Hectare & Parameters \\
\cline { 3 - 6 } & 368 & 8.96 & 0.189 & $0.018^{* * *}$ & Big game \\
\hline Hunter & & $(21.64)^{2}$ & $(0.0289)$ & $(0.004)$ & $0.054^{* * *}$ \\
$\quad$ days & 245 & $1.12^{* * *}$ & 0.0005 & -0.000009 & $(0.013)$ \\
$\begin{array}{l}\text { Increased labor } \\
\text { days/yr) }\end{array}$ & & $(0.104)$ & $(0.0012)$ & $0.00001)$ & $0.0002^{* * *}$ \\
$\begin{array}{l}\text { Fencing \& materials costs } \\
\text { (days/yr) }\end{array}$ & 247 & $1.24^{* * *}$ & $0.005^{* *}$ & 0.00004 & $(0.00005)$ \\
\hline
\end{tabular}

$1 *, * *, * * *$ Significant at the $0.05,0.01$, and 0.001 levels, respectively.

2 Standard error. 
southwestern Montana may be expected to request a reduction in number of big game animals on private lands.

\section{Literature Cited}

Adkins, R.J. 1991. An analysis of game damage and game damage complaints in Montana. MS Thesis, Montana State Univ., Bozeman.

Applegate, J.E. 1981. Landowner's behavior in dealing with wildlife values. In: Robert T. Dumke, George V. Burger, and James R. March (eds.). Wildlife management on private lands, Wisconsin Dep. of Natur. Resourc. Madison, Wisc.

Austin, D.D., and P.J. Urness. 1987. Consumption of fresh alfalfa hay by mule deer and elk. Great Basin Natur. 47:100-102.

Brooks, R. 1988. The net economic value of deer hunting in Montana. Montana Dep. Fish, Wildl. and Parks. Helena, Mont.

Coleman, J.S. 1990. Foundations of social theory. Harvard Univ. Press, Cambridge.

Dillman, D.A. 1978. Mail and telephone surveys: the total design method. John Wiley and Sons. N.Y.

Duffield, J. 1988. The net economic value of elk hunting in Montana. Mont. Dep. Fish, Wildl. and Parks. Helena, Mont.

Edge, W.D., and C.L. Marcum. 1990. Elk and cattle on public lands: a new look at an old conflict. Western Wildlands Summer: 12-15.

Gasson, W. 1985. Capitalizing on Wyoming's game and fish resources. In J. Powell (ed.) Holistic Ranch Management Workshop Proc. Wyo. Agr. Ext. Serv. May 28-30, 1985. Casper, Wyo.

Gillis, A.M. 1991. Should cows chew cheatgrass on common lands? Bio. Sci. 41:668-675.

Hadley, K., and N. Carroll. 1986. From conflict to cooperation. Proc. Montana Landowner's and Sportsmen's conference. April 18-20, 1986. Fairmont Hot Springs, Mont.

Headwaters, RC\&D. 1974. Headwaters RC\&D project plan Montana. Assisted by USDA, Soil Conserv. Serv. and other Cooperating Agencies. Butte, Mont.

Headwaters, RC\&D. 1990. People working together in the 1990's. A landowners/sportsmen conference to identify common ground. 28 April 1990. Butte, Mont.

Hosmer, D.W., Jr., and S. Lemeshow. 1989. Applied logistic regression, John Wiley \& Sons.

Jackson, J.M. 1991. Impact of elk in Catron County, New Mexico. Rangelands 13:287-290.

Jordan, L.A., and J.P. Workman. 1989. Economics and management of fee hunting for deer and elk in Utah. Wildl. Soc. Bull. 17:482-487.

Kmenta, J. 1986. Elements of econometrics. Macmillan Publ. Co., Inc. N.Y.

Kramer, B.M. 1982. Legal aspects of use and development of wildlife resources on private lands: Colorado, Kansas, New Mexico, Oklahoma, Texas. Great Plains Agr. Counc. Wildl. Resour. Comm. Great Plains Agr. Counc. Pub. 103.
Krutilla, J.V. 1967. Some environmental effects of economic development. Daedalus 96:1058-1070.

Lacey, J.R., and J.B. Johnson. 1990. Livestock grazing on federal lands: a boon to Montana's economy. Western Wildlands. 16:23-26.

Lacey, J.R., S.B. Laursen, J.C. Gilchrist, R.M. Brownson, J. Anzick, and S. Doggett. 1988. Economic and social implications of managing wildlife on private land in Montana. Northwest Sci. 62:1-9.

Loomis, J., and J. Cooper. 1988. The net economic value of antelope hunting in Montana. Mont. Dep. of Fish Wildl. and Parks. Helena, Mont.

McKetta, C., and N. Bolon. 1990. Idaho landowners' attitudes on hunting and hunters. Idaho Forest Wildl. and Range Exp. Sta. Focus 15:3-4.

Montana Department of Fish, Wildlife, and Parks. 1986-1987a. Big game survey and inventory, Region 2 . Job Prog. Rep., Survey and Inventory Proj. Job 1-2 Elk and Deer.

Montana Department of Fish, Wildlife, and Parks. 1986-1987b. Big game survey and inventory, Region 3. Job Prog. Rep., Survey and Inventory Proj. Job 1-3 (Segment-B) Elk.

National Wildlife Federation, Montana Wildlife Federation, and Skyline Sportsmen. 1990. Appeal of the 1990 Plan of Use for the Upper Ruby Cattle and Horse Allotment. Notice of Appeal, Statement of reasons, and request for stay. United States Forest Service, Sheridan Ranger District are appellees.

Nielsen, D.B., and K. McBride. 1989. Losses on private land due to big-game animals. Utah Agr. Exp. Sta., Utah Sci. Summer.

Nielsen, D.B., F.J. Wagstafi, and D. Lytle. 1986. Big-game animals on private range. Rangelands 8:36-38.

Peek, J.M. 1986. A review of wildlife management. Prentice-Hall. Englewood Cliffs. N.J.

Pineo, D. 1985. Wildlife and recreation management on private lands-A guide for Washington. Produced in cooperation with: Washington Farm Bureau, Washington Dairymen-Federation, Washington Cattlemen's Assoc., Washington Forest Protect. Assoc., and Washington Farm Forest. Assoc.

Rimbey, N.R., R.L. Gardner, and P.E. Patterson. 1991. Wildlife depredation policy development. Rangelands 13:272-275.

Smith, D.R. 1961. Competition between cattle and game on elk winter range. Univ. of Wyo., Agr. Exp. Sta. Bull. 377.

Stoddard, L.A., A.D. Smith, and T.W. Box. 1975. Range management. Third Ed. McGraw-Hill Book Co., N.Y.

Stoddard, L.A., and A.D. Smith. 1955. Range management. Second Ed. McGraw-Hill Book Co. N.Y.

Thomas, J.W. 1984. Fee-hunting on the public's lands?-An appraisal. Trans. North Amer. Wildl. Natur. Resour. Conf. 49:455-467.

Torell, L.A., and J.P. Doll. 1991. Public land policy and the value of grazing permits. W.J. Agr. Econ. 16:174-184.

U.S. Census of Agriculture. 1987. Montana State and County Data. Geographic Area Services. Vol. 1, Part 26. Washington, D.C.

USDA National Agricultural Statistics Service. 1990. Agricultural prices: 1989 Summary. Agr. Stat. Board. Washington, D.C. p. B-60. 